УДК 547.9:582.284.5

\title{
ЛИПОФИЛЬНЫЕ КИСЛОТЫ ИВАН-ЧАЯ УЗКОЛИСТНОГО
}

() Т.П. Кукина ${ }^{* 1}$, Т.С. Фролова ${ }^{1,2}$, О.И. Сальникова ${ }^{1}$

${ }^{1}$ Новосибирский институт органической химии СО РАН им. Н.Н. Ворожцова, пр. Академика Лаврентьева, 9, Новосибирск, 630090 (Россия), e-mail:kukina@nioch.ncs.ru

${ }^{2}$ Новосибирский государственный университет, ул. Пирогова, 2, Новосибирск, 630090 (Россия)

Проведен хроматомасс-спектрометрический анализ липофильных кислот иван-чая узколистного (Chamaenerion angustifolium (L.) Scorp.). Впервые обнаружены 36 алифатических и 5 тритерпеновых кислот.

Ключевые слова: иван-чай узколистный (Chamaenerion angustifolium (L.) Scorp.), хроматомасс-спектрометрия, липофильные кислоты.

\section{Введение}

Иван-чай узколистный (Chamaenerion angustifolium (L.) Scorp.) - широко распространенное по всему миру растение. Хорошо известно его пищевое и лекарственное применение. Иван-чай является сидеральной культурой, идеально пригодной для фиторекультивации почв. Тем не менее поиск литературных источников и интернет-ресурсов с информацией о химическом составе экстрактивных веществ этого растения не приводит к сколько-нибудь значимым результатам. Причина заключается в том, что выделение иван-чая в отдельный род из рода кипреев на основании морфологических признаков [1, 2] не признано частью ботаников [3], а фитохимики и фармацевты чаще используют прежнее название кипрей узколистный (Epilobium angustifolium L.). Сведений о составе Epilobium angustifolium существенно больше, но они касаются по большей части полярных водо- и спирторастворимых компонентов. Так, для иван-чая идентифицированы фенолокислоты (производные бензойной и коричной кислот) [4], гликозидированные и свободные флавоноиды [5-7].

В то же время в литературе имеется немало данных об использовании растений, выращенных на рекультивированных землях, в качестве лекарственного сырья. Эти данные свидетельствуют, что предпочтительнее использовать липофильные компоненты БАВ, так как они менее загрязнены полютантами [8]. Про иван-чай известно, что он практически не накапливает тяжелых металлов [9, 10] и радионуклидов [11]. Так, коэффициент накопления радионуклидов иван-чаем, выращенным в зоне, подвергшейся воздействию Чернобыльской катастрофы, в 1,3 раза ниже, чем у энотеры, принадлежащей к тому же семейству, в 5,2 раза ниже, чем у донника белого, в 22 раза ниже, чем у чабреца [9]. Тем не менее использование только липофильных компонентов более надежно гарантирует безопасность полученного препарата. Состав липофильных компонентов иван-чая практически не изучен, хотя имеется ряд сведений о составе монотерпенов [12], алифатических кислот [13-14], токоферолов [14], стеринов [15, 16] и тритерпеноидов [17]. В составе липофильных компонентов иван-чая обнаружены 3-гексен-1-ол, 3-туйен, $\alpha$-пинен, камфен, бензальдегид, $\Delta^{3}$-карен, 4-этил-1,2-диметилбензол, лимонен,

Кукина Татьяна Петровна - старший научный сотрудник, доцент, кандидат химичеких наук, тел.: (383) 30-75-44, e-mail: kukina@ nioch.nsc.ru Фролова Татьяна Сергеевна - инженер второй категории, аспирант, тел.: (383) 30-75-44, e-mail: frolova@bionet.nsc.ru Сальникова Ольга Иосифовна - ведущий инженер, e-mail: olga@nioch.nsc.ru бензоацетоальдегид, фелландрен, линалоол, камфара, терпинеол, линалилпропиат, эвгенол [12], $\beta$-ситостерин и его эфиры $[15,16]$, пальмитиновая, стеариновая, олеиновая, линолевая, линоленовая [13, 14], урсоловая, олеаноловая, маслиновая и 2- $\alpha$-гидроксиурсоловая (коросоловая) кислоты [17], однако количественные дан-

\footnotetext{
* Автор, с которым следут вести переписку.
} 
ные приведены без детализации. При этом алифатические кислоты изучались только для генеративных органов растения. Обнаружение в составе сырья иван-чая разнообразных тритерпеновых кислот представляет интерес из-за широкого спектра их физиологической активности. Наиболее распространенные тритерпеновые кислоты урсанового и олеананового ряда - урсоловая и олеаноловая. Они и родственные им соединения обладают выраженной биологической активностью в разнообразных медико-биологических тестах [18-29]. Активность их различается, в ряде тестов олеаноловая кислота превосходит урсоловую [30]. В то же время выявлены активные свойства алифатических кислот, в том числе противораковые [31-36].

Цель нашей работы - анализ липофильных кислот иван-чая и определение частей растения, наиболее пригодных для препаративной наработки того или иного БАВ. Попутно решалась задача оптимизации сроков сбора сырья. Признано, что для хемотаксономии кипрейных важен состав кислых компонентов экстрактивных веществ [14], поэтому на первом этапе работа заключалась в установлении состава алифатических и тритерпеновых кислот, которыми, как известно, богато сырье иван-чая.

\section{Экспериментальная часть}

Характеристика сырья. Сырье иван-чая (ИЧ) было заготовлено 30 июня 2008 г., 15 июля и 20 сентября 2009 г., 30 июня и 18 сентября 2010 г. на территории ЦСБС СО РАН Новосибирска, а также 15 сентября 2008 г. в районе деревни Падун Черепановского района НСО. В ходе исследования сырье фракционировали на стебли, листья и цветочные побеги с цветками. В сырье сбора 2009 г. дополнительно выделены фракции цветков, плодов и цветочных побегов.

Экстракция сырья. Воздушно-сухое сырье размолото на электрической мельнице и просеяно через сито с отверстиями размером 2 мм. Экстракция проводилась ступенчато в проточном перколяторе. Навеска сырья загружалась в перколятор, заливалась порцией экстрагента, нагретого до $50{ }^{\circ} \mathrm{C}$, настаивалась в течение 1-1,5 ч, экстракт сливался через нижний кран. Сырье заливали растворителем с таким расчётом, чтобы слой растворителя над сырьём был 1,5-2,0 см. При этом гидромодуль (соотношение растворитель : сырье) составляет 1,5-2. Процесс повторяли 3-4 раза. Порции экстракта выпаривались на роторном испарителе досуха для определения массового выхода экстрактивных веществ. Экстракты, богатые липофильными компонентами, были получены путем применения метил-трет-бутилового эфира (МТБЭ).

Bыделение свободных кислот. Навеска исследуемого экстракта растворялась в метил-трет-бутиловом эфире до получения раствора с концентрацией 1-5\%. Раствор помещали в делительную воронку объемом 200-300 мл и экстрагировали 2\% водным раствором едкого натра с добавлением $10 \%$ по объему этанола (3×50 мл). Объединенный водный слой, содержащий натриевые соли кислых компонентов, подкисляли $10 \%$ водным раствором соляной кислоты до $\mathrm{pH}=2$ и экстрагировали в делительной воронке метил-третбутиловым эфиром (3×50 мл). Объединенные эфирные вытяжки отмывали в делительной воронке дистиллированной водой до нейтральной реакции ( $\mathrm{pH}=7)$ по универсальному индикатору, сушили над безводным сульфатом натрия и упаривали досуха на роторном испарителе при пониженном (20-30 мм рт.ст.) давлении, обусловленном применением водоструйного насоса. Выход свободных кислот сведен в таблицу 1.

Bыделение неомыляемых веществ экстрактов. Освобожденные от свободных кислот экстракты отмывали от остатков водно-щелочного экстрагента дистиллированной водой на делительной воронке до нейтральной реакции. Эфирные растворы сушили над безводным сульфатом натрия в течение 2 ч, отфильтрованные от осушителя растворы вакуумировали. После удаления растворителя образцы экстрактов растворяли в омыляющей смеси, содержащей $15 \%$ едкого натра, $10 \%$ дистиллированной воды и $75 \%$ этилового спирта по весу, из расчета 10-кратного количества омыляющей смеси по отношению к взятой навеске. Смесь кипятили на магнитной мешалке с подогревом при интенсивном перемешивании в колбе, снабженной обратным холодильником с водяным охлаждением, в течение 1,5 ч. После окончания реакции (контроль вели по ТСХ до исчезновения фракции сложных эфиров) реакционную смесь разбавляли водой в 4 раза и экстрагировали в делительной воронке свежеперегнанным метил-трет-бутиловым эфиром (4×100 мл). Объединенные эфирные вытяжки отмывали на делительной воронке дистиллированной водой (4×100 мл), сушили над безводным сульфатом натрия и вакуумировали. Выход неомыляемых веществ из экстрактов, освобожденных от свободных кислот, приведен в таблице 1 .

Омыление экстракта. Экстракты, полученные из образцов сырья, количество которого не позволяло получить более 1 г экстракта, делили путем общепринятой процедуры омыления без предварительного отделения свободных кислот на суммарные кислые компоненты и суммарные неомыляемые вещества аналогично предыдущему пункту. Выход неомыляемых веществ из экстрактов изучаемых образцов сырья приведен в таблице 1 . 
Таблица 1. Выход кислых фракций и неомыляемых веществ из МТБЭ-экстрактов (\% от веса воздушносухого сырья)

\begin{tabular}{l|c|c|c|c}
\hline \multicolumn{1}{c|}{ Образец сырья } & $\begin{array}{c}\text { Свободные } \\
\text { кислоты }\end{array}$ & $\begin{array}{c}\text { Связанные } \\
\text { кислоты }\end{array}$ & $\begin{array}{c}\text { Суммарные ки- } \\
\text { слоты }\end{array}$ & $\begin{array}{c}\text { Неомыляемый } \\
\text { остаток (НО) }\end{array}$ \\
\hline Листья июль & 1,1 & 1,5 & 2,6 & 2,2 \\
Стебли июль & 0,6 & 0,2 & 0,8 & 0,3 \\
Листья сентябрь & 1,5 & 1,5 & 3,0 & 2,6 \\
Стебли сентябь & 1,0 & 0,3 & 1,3 & 0,3 \\
Генеративные побеги с цветами* & & & 0,8 & 1,0 \\
Генеративные побеги * & & & 0,45 & 1,3 \\
Цветы & 0,9 & 0,8 & 1,7 & 0,7 \\
Плоды * & & & 1,0 & 1,3 \\
\hline
\end{tabular}

* разделение на свободные и связанные кислоты не проводилось.

Bыделение связанных кислот. Реакционные смеси после отделения неомыляемых веществ подкисляли $10 \%$ соляной кислотой до $\mathrm{pH} 2$ и экстрагировали свежеперегнанным метил-трет-бутиловым эфиром в делительной воронке (3×100 мл). Объединеные эфирные вытяжки промывали дистиллированной водой и сушили над безводным сульфатом натрия. Профильтрованный от осушителя раствор вакуумировали на ротационном испарителе до полного удаления растворителя. Выход кислых компонентов в процентах от веса воздушно-сухого сырья приведен в таблице 1.

Исчерпьвающее метилирование кислот диазометаном. Навеску кислот растворяли в свежеперегнанном диэтиловом эфире с добавкой метанола и добавляли порциями эфирный раствор диазометана. Контроль за реакцией осуществляли визуально по изменению окраски раствора и прекращению выделения пузырьков азота. Окончание реакции определяли по ТСХ реакционной смеси: добавление раствора диазометана прекращали, когда на ТС-хроматограмме полностью исчезало пятно неметилированных кислот. Для тонкослойной хроматографии использовали пластинки Sorbfil в системе гексан : МТБЭ 1 : 1. Пластинки опрыскивали смесью ванилин - серная кислота - этанол $1: 10: 90$ и для полного проявления нагревали до $100{ }^{\circ} \mathrm{C}$. Полученные метиловые эфиры анализировали при помощи хроматомасс-спектрометрии свежеприготовленными.

Хроматомасс-спектрометрия. Хроматомасс-спектры записаны на приборе Hewlett Packard G 1800 A, состоящем из газового хроматографа НР 5890 серии II и масс-селективного детектора НР 5971. Колонка 30 м $\times 0,25$ мм $\times 0,25$ мкм с сорбентом HP-5MS (5\% - дифенил, 95\% - диметилсилоксан). Газ-носитель - гелий (1 мл/мин). Температура колонки: 2 мин. при $50{ }^{\circ} \mathrm{C}$, далее повышение температуры со скоростью $4^{\circ}$ в мин до $300{ }^{\circ} \mathrm{C}, 30$ мин при $300{ }^{\circ} \mathrm{C}$. Температура испарителя $280{ }^{\circ} \mathrm{C}$, источника ионов $170{ }^{\circ} \mathrm{C}$.

\section{Обсуждение результатов}

Анализируя выход экстрактивных веществ из образцов сырья, а также кислых и нейтральных компонентов, полученных при омылении метил-трет-бутиловых экстрактов, представленных в таблице 1 , обнаруживаем следующие факты. Метил-трет-бутиловым эфиром экстрагируется от 1,1 до 5,6 \% (без учета потерь при фракционировании) липофильных веществ. При этом наибольшее количество экстрактивных веществ экстрагируется из листьев, наименьшее - из стеблей. Кислые компоненты в свободном виде составляют от 0,6 до 1,50\%, в связанном виде - 0,2-1,5\% от веса исследованного сырья. Все кислые фракции метилировали и передавали в группу ХМС лаборатории физических методов исследования НИОХ СО РАН. Таблицы 2-4 иллюстрируют качественный и усредненный количественный состав фракций свободных и связанных кислот вегетативных и генеративных органов иван-чая узколистного из сырья, собранного в 2008-2010 гг.

Таблица 2. Кислоты, идентифицированные при помощи ХМС-анализа в вегетативных органах иван-чая сбора 2008-2010 г. (июль) (\% от веса фракции)

\begin{tabular}{|c|c|c|c|c|}
\hline Кислота & $\begin{array}{c}\text { Листья } \\
\text { (свободные) }\end{array}$ & $\begin{array}{c}\text { Листья } \\
\text { (связанные) }\end{array}$ & $\begin{array}{c}\text { Стебли } \\
\text { (свободные) }\end{array}$ & $\begin{array}{c}\text { Стебли } \\
\text { (связанные) }\end{array}$ \\
\hline 1 & 2 & 3 & 4 & 5 \\
\hline Каприновая $\mathrm{C}_{10} *$ & 0,12 & 0,36 & 0,10 & 0,11 \\
\hline Лауриновая $\mathrm{C}_{12} *$ & 0,23 & 2,09 & 0,18 & 0,72 \\
\hline Миристиновая $\mathrm{C}_{14}$ * & 1,59 & 10,4 & 0,54 & 2,77 \\
\hline Пентадекановая $\mathrm{C}_{15}$ * & 0,38 & 0,26 & 0,58 & 0,71 \\
\hline
\end{tabular}


Окончание таблиць 2

\begin{tabular}{|c|c|c|c|c|}
\hline 1 & 2 & 3 & 4 & 5 \\
\hline Пентадеценовая $\mathrm{C}_{15: 1}$ * & 0,10 & 0,22 & 0,16 & 1,72 \\
\hline Пальмитиновая $\mathrm{C}_{16}$ & 15,27 & 23,18 & 27,80 & 25,64 \\
\hline Пальмитолеиновая $\mathrm{C}_{16: 1}$ * & 0,36 & 0,51 & 0,40 & 0,72 \\
\hline Маргариновая $\mathrm{C}_{17} *$ & 0,20 & 0,44 & 0,84 & 0,75 \\
\hline Стеариновая $\mathrm{C}_{18}$ & 1,73 & 4,50 & 2,98 & 3,47 \\
\hline Олеиновая $\mathrm{C}_{18: 1}$ & Следы & 0,46 & 1,62 & 1,50 \\
\hline Линолевая $\mathrm{C}_{18: 2}$ & 5,55 & 13,25 & 14,0 & 24,83 \\
\hline Линоленовая $\mathrm{C}_{18: 3}$ & 10,55 & 24,86 & 13,61 & 14,58 \\
\hline Линоленовая $\mathrm{C}_{18: 3}$ * & 0,24 & & 1,60 & \\
\hline Нонадекановая $\mathrm{C}_{19}$ * & Следы & & 0,30 & 0,45 \\
\hline Арахиновая $\mathrm{C}_{20}$ * & 1,71 & 5,75 & 4,02 & 8,94 \\
\hline Генэйкозановая $\mathrm{C}_{21}$ * & 0,12 & 0,36 & 0,88 & 0,77 \\
\hline Бегеновая $\mathrm{C}_{22} *$ & 1,00 & 1,56 & 1,02 & 2,14 \\
\hline Трикозановая $\mathrm{C}_{23}$ * & 0,22 & 0,23 & 0,26 & 0,67 \\
\hline Тетракозановая $\mathrm{C}_{24}$ * & 1,61 & 2,03 & 0,62 & 0,82 \\
\hline 2-Гидрокситрикозановая* & & & & 0,26 \\
\hline Пентакозановая $\mathrm{C}_{25}$ * & 0,10 & 1,2 & 0,18 & 0,51 \\
\hline 2-Гидрокситетракозановая* & & 0,31 & & 0,58 \\
\hline Гексакозановая $\mathrm{C}_{26}$ * & 0,86 & 1,71 & 1,64 & 1,31 \\
\hline Гептакозановая $\mathrm{C}_{27}$ * & Следы & 0,81 & 0,14 & 0,47 \\
\hline 2-Гидроксигексакозановая* & & 0,64 & & \\
\hline Октакозановая $\mathrm{C}_{28}$ * & 0,58 & 1,82 & 2,88 & 2,02 \\
\hline Нонакозановая $\mathrm{C}_{29}$ * & Следы & 0,47 & Следы & 0,34 \\
\hline 2-Гидроксиоктакозановая* & & 0,55 & & \\
\hline Триаконтановая $\mathrm{C}_{30}$ * & 0,17 & 0,96 & 1,62 & 1,25 \\
\hline 2-Гидрокситриаконтановая* & & 0,26 & & \\
\hline Олеаноловая & 10,00 & & 2,92 & \\
\hline Урсоловая & 37,00 & & 17,6 & \\
\hline Урсоновая* & 1,09 & & 0,38 & \\
\hline Олеаноновая* & 0,34 & & 0,12 & \\
\hline Ацетилурсоловая* & 0,18 & & 0,58 & \\
\hline Помоловая* & 5,36 & & 7,22 & \\
\hline
\end{tabular}

* Идентифицировано в сырье иван-чая узколистного впервые.

Таблица 3. Кислоты, идентифицированные при помощи ХМС-анализа в вегетативных органах иван-чая сбора 2008-2010 гг. (сентябрь) (\% от веса фракции)

\begin{tabular}{l|c|c|c|c}
\hline \multicolumn{1}{c|}{ Вещество/образец } & $\begin{array}{c}\text { Листья } \\
\text { (свободные) }\end{array}$ & $\begin{array}{c}\text { Листья } \\
\text { (связанные) }\end{array}$ & $\begin{array}{c}\text { Стебли } \\
\text { (свободные) }\end{array}$ & $\begin{array}{c}\text { Стебли } \\
\text { (связанные) }\end{array}$ \\
\hline \multicolumn{1}{c|}{1} & 2 & 3 & 4 & 5 \\
\hline Каприновая $\mathrm{C}_{10} *$ & 0,13 & 0,18 & 0,15 & 0,10 \\
Лауриновая $\mathrm{C}_{12} *$ & 0,28 & 0,45 & 0,23 & 3,89 \\
Миристиновая $\mathrm{C}_{14} *$ & 0,92 & 9,80 & 0,22 & 1,73 \\
Пентадекановая $\mathrm{C}_{15} *$ & 0,86 & 0,42 & 0,16 & 1,41 \\
Пентадеценовая $\mathrm{C}_{15: 1} *$ & 0,66 & 0,11 & 0,12 & 33,7 \\
Пальмитиновая $\mathrm{C}_{16}$ & 6,47 & 25,30 & 16,11 & 0,28 \\
Пальмитолеиновая $\mathrm{C}_{16: 1} *$ & 0,62 & 0,42 & 0,24 & 6,44 \\
Маргариновая $\mathrm{C}_{17} *$ & 0,14 & 0,67 & 0,23 & 0,88 \\
Стеариновая $\mathrm{C}_{18}$ & 1,51 & 5,96 & 5,44 & 6,14 \\
Олеиновая $\mathrm{C}_{18: 1}$ & 0,4 & 0,47 & 1,12 & 8,24 \\
Линолевая $\mathrm{C}_{18: 2}$ & 1,03 & 9,37 & 9,11 & 0,46 \\
Линоленовая $\mathrm{C}_{18: 3}$ & 2,00 & 16,81 & 9,33 & 5,12 \\
Нонадекановая $\mathrm{C}_{19} *$ & 0,40 & 0,48 & 0,47 & 0,87 \\
Арахиновая $\mathrm{C}_{20} *$ & 6,49 & 2,37 & 0,82 \\
Эйкозандиовая $\mathrm{C}_{20} *$ & 1,05 & & & 1,95 \\
Генэйкозановая $\mathrm{C}_{21} *$ & & 0,72 & 0,84 & 0,45 \\
Бегеновая $\mathrm{C}_{22} *$ & 2,02 & 0,17 & \\
Докозандиовая $\mathrm{C}_{22} *$ & 0,75 & & & \\
\hline
\end{tabular}


Окончание таблиць 3

\begin{tabular}{l|c|c|c|c}
\hline \multicolumn{1}{c|}{$l$} & 2 & 3 & 4 & 5 \\
\hline Трикозановая $\mathrm{C}_{23} *$ & 0,24 & 0,93 & 0,37 & 0,65 \\
Тетракозановая $\mathrm{C}_{24} *$ & 2,56 & 2,68 & 2,69 & 1,95 \\
Пентакозановая $\mathrm{C}_{25} *$ & 0,20 & 1,23 & 0,34 & 0,24 \\
Гексакозановая $\mathrm{C}_{26} *$ & 3,80 & 3,22 & 4,73 & 3,10 \\
Гептакозановая $\mathrm{C}_{27} *$ & & 1,47 & 0,43 & 5,93 \\
Октакозановая $\mathrm{C}_{28} *$ & 2,92 & 3,14 & 5,41 & 0,16 \\
Нонакозановая $\mathrm{C}_{29} *$ & & 0,82 & 0,27 & 4,91 \\
Триаконтановая $\mathrm{C}_{30} *$ & 0,71 & 1,29 & 3,16 & \\
Олеаноловая & 8,33 & & 10,22 & \\
Урсоловая & 44,11 & & 1,51 & \\
Урсоновая* & 0,20 & & 0,26 & \\
Олеаноновая* & 0,10 & & 0,12 & \\
Ацетилурсоловая* & 0,33 & & & \\
Ацетилолеаноловая* & 0,14 & & & \\
Помоловая* & 10,39 & & & \\
\hline
\end{tabular}

* Идентифицировано в сырье иван-чая узколистного впервые.

Таблица 4. Кислоты, идентифицированные при помощи ХМС-анализа в генеративных органах иван-чая сбора 2008-2010 г. (июль) (\% от веса фракции)

\begin{tabular}{|c|c|c|c|c|c|}
\hline Вещество/образец & $\begin{array}{c}\text { Генеративные } \\
\text { побеги с цветками }\end{array}$ & $\begin{array}{c}\text { Генеративные } \\
\text { побеги } \\
\end{array}$ & $\begin{array}{c}\text { Цветки } \\
\text { (свободные) } \\
\end{array}$ & $\begin{array}{c}\text { Цветки } \\
\text { (связанные) }\end{array}$ & Плоды \\
\hline Каприновая $\mathrm{C}_{10}$ * & 0,18 & 0,11 & 0,44 & 0,24 & 0,12 \\
\hline 3-Гидроксидекановая & 0,27 & & 0,16 & 0,92 & \\
\hline Лауриновая $\mathrm{C}_{12} *$ & 0,25 & 0,34 & 0,76 & 0,57 & 0,44 \\
\hline 3-Гидроксидодекановая & 0,57 & & 2,52 & 13,27 & 1,2 \\
\hline Миристиновая $\mathrm{C}_{14}$ * & 2,68 & 3,66 & 1,80 & 3,87 & 2,73 \\
\hline 9-Гидроксиундекановая & Следы & & 0,33 & & \\
\hline Пентадекановая $\mathrm{C}_{15}$ * & 0,42 & 1,08 & 0,30 & 0,46 & 1,16 \\
\hline Пальмитиновая $\mathrm{C}_{16}$ & 36,14 & 38,57 & 20,69 & 34,12 & 36,92 \\
\hline Пальмитолеиновая $\mathrm{C}_{16: 1}$ * & & & & & 0,48 \\
\hline Маргариновая $\mathrm{C}_{17} *$ & 0,75 & 1,18 & 0,49 & 0,69 & 1,24 \\
\hline Стеариновая $\mathrm{C}_{18}$ & 5,72 & 4,16 & 4,08 & 6,32 & 2,01 \\
\hline Олеиновая $\mathrm{C}_{18: 1}$ & 1,24 & 1,45 & 0,93 & 0,73 & 2,54 \\
\hline Линолевая $\mathrm{C}_{18: 2}$ & 2,93 & 8,73 & 5,02 & 3,76 & 14,2 \\
\hline Линоленовая $\mathrm{C}_{18: 3}$ & 3,79 & 8,20 & 6,72 & 4,38 & 14,05 \\
\hline$\gamma$-Линоленовая $\mathrm{C}_{18: 3}$ * & & 1,83 & & & 2,99 \\
\hline 16-Гидрокси-гексадекановая* & 0,10 & & 0,33 & & \\
\hline Гексадекандиовая кислота* & 0,21 & & 1,10 & & \\
\hline Арахиновая $\mathrm{C}_{20}$ * & 4,78 & 4,97 & 4,59 & 6,31 & 3,64 \\
\hline 11,14-Эйкозадиеновая* & & & 0,69 & & \\
\hline $9,11,13,15$-октакозантетраеновая* & & & 0,81 & & \\
\hline Гадолеиновая* & 0,38 & & 1,39 & 7,78 & \\
\hline 11-Эйкозеновая* & 0,21 & & 3,13 & & \\
\hline Генэйкозановая $\mathrm{C}_{21}$ * & 1,75 & 0,78 & 0,93 & & 1,05 \\
\hline Бегеновая $\mathrm{C}_{22} *$ & 2,27 & 1,1 & 1,89 & 3,82 & 1,03 \\
\hline Трикозановая $\mathrm{C}_{23}$ * & 1,03 & 0,37 & 0,59 & 0,42 & 0,34 \\
\hline Тетракозановая $\mathrm{C}_{24} *$ & 1,68 & 0,49 & 3,15 & 3,08 & 0,43 \\
\hline Пентакозановая $\mathrm{C}_{25} *$ & 0,33 & 0,20 & 0,30 & & \\
\hline Гексакозановая $\mathrm{C}_{26}$ * & 1,59 & 0,66 & 1,72 & 1,61 & \\
\hline Гептакозановая $\mathrm{C}_{27} *$ & 0,24 & Следы & 0,13 & & \\
\hline Октакозановая $\mathrm{C}_{28}$ * & 1,69 & 1,05 & 1,17 & 1,32 & \\
\hline Нонакозановая $\mathrm{C}_{29}$ * & 0,28 & Следы & Следы & & \\
\hline Триаконтановая $\mathrm{C}_{30}$ * & 1,09 & 0,72 & 0,62 & 0,42 & \\
\hline Олеаноловая & 2,29 & 0,95 & 1,62 & & 0,79 \\
\hline Урсоловая & 5,04 & 4,43 & 7,98 & & 5,25 \\
\hline Урсоновая* & 0,38 & & 0,28 & & Следы \\
\hline Олеаноновая* & 0,11 & & & & Следы \\
\hline Помоловая* & 0,72 & 2,8 & 3,17 & & 0,73 \\
\hline
\end{tabular}


Из таблиц следует, что применение высокотемпературных условий хроматомассспектрометрического анализа кислых компонентов приводит к идентификации более широкого спектра соединений. Впервые в сырье иван-чая узколистного выявлено более 40 кислот, в том числе высокоактивные тритерпеновые компоненты урсоновая, олеаноновая, ацетилурсоловая, ацетилолеаноловая, помоловая кислоты, а также каприновая, лауриновая, миристиновая, пентадекановая, пентадеценовая, пальмитолеиновая, маргариновая, $\gamma$-линоленовая, нонадекановая, арахиновая, генэйкозановая, бегеновая, трикозановая, тетракозановая, пентакозановая, гексакозановая, гептакозановая, октакозановая, нонакозановая, триаконтановая, 2-гидрокситрикозановая, 2-гидрокситетракозановая, 2-гидроксигексакозановая, 2-гидроксиоктакозановая, 2-гидрокситриаконтановая, гексадекандиовая, октадекандиовая, эйкозандиовая, 11,14эйкозадиеновая, докозандиовая, 3-гидроксидекановая, 3-гидроксидодекановая, 9-гидроксиундекановая, 9, 11, 13, 15-октакозановая, гадолеиновая, 11-эйкозеновая.

\section{Выводы}

1. Методом хроматомасс-спектрометрии исследован состав липофильных кислот вегетативных и генеративных органов иван-чая узколистного.

2. Впервые идентифицировано в этом виде сырья 36 алифатических и 5 тритерпеновых кислот.

3. Проведен сравнительный анализ кислых компонентов в вегетативных органах в середине и конце периода вегетации.

\section{Список литературы}

1. Королёва А.С., Красноборов И.М., Пеньковская Е.Ф. Определитель растений Новосибирской области. Новосибирск, 1973. 368 с.

2. Красноборов И.М., Ломоносова М.Н., Шауло Д.Н. и др. Определитель растений Новосибирской области. Новосибирск, 2000, 492 с.

3. Тахтаджян А.Л. Жизнь растений. Т. 5, ч. 2: Цветковые растения. М., 1980. 512 с.

4. Hiermann A., Radl B., Analysis of aromatic plant acids by capillary zone electrophoresis // J. Chromatog. A. 1998. Vol. 803, N 1. Pp. 311-314.

5. Ducrey, B., Wolfender, J.L., Marston, A., Hostettmann, K., Analysis of flavonolglycosides of thirtheen Epilobium species (Onagraceae) y LC-UV and thermospray LC-MS // Phytochemistry. 1995. Vol. 38, N 1. Pp. 129-137.

6. Slacanin I., Marston A., Hostettmann K., Delabays N., Darbellay C. Isolation and determination of flavonol glycosides from Epilobium species // J. Chromatogr. 1991. Vol. 557, N 1-2. Pp. 391-398.

7. Hiermann A., Phytochemical characterization of Epilobium angustifolium L. and its differentiation to other Epilobium species by TLC and HPLC // Scientia Pharmaceutica. 1995. Vol. 63, N 2. Pp. 135-144.

8. Шмонов А.М. Возможности использования рекультивированных земель Кузбасса для создания заготовительной базы облепихового сырья // Новое в биологии, химии и фармакологии облепихи. Новосибирск, 1991. C. $191-189$.

9. Полежаева И.В., Полежаева Н. И., Меняйло Л. Н. Исследование минерального комплекса вегетативной части Chamerion angustifolium (L.) Holub // Химия растительного сырья. 2005. №4. С. 67-70.

10. Полежаева И. В., Полежаева Н. И., Левданский В.А. Сравнительное исследование химического состава кипрея узколистного Chamerion angustifolium (L.) Holub // Вестник КрасГУ. Серия «Естественные науки». 2005. №2. С. 130-133.

11. Сапегин Л. М., Дайнеко Н. М., Тимофеев С.Ф. Радиоактивное загрязнение растений в Чечерском районе Гомельской области // Растительные ресурсы. 2008. Т. 44, №4. С. 85-91.

12. Полежаева И. В. Изучение экстракции сжиженной углекислотой надземной части Chamerion angustifolium $(L$.) Holub. // Новые достижения в химии и химической технологии растительного сырья: матер. IV Всероссийской конф. Барнаул, 2007. С. 66-70.

13. Hiermann A., Bucar F. Studies of Epilobium angustifolium extracts on growth of accessory sexual organs in rats // J. Ethnopharmacol. 1997. Vol. 55. Pp. 179-183.

14. Velasco L., Goffman F.D. Tocopherol and fatty acid composition of twenty-five species of Onagraceae Juss // Botan. J. Linnean Soc. 1999. Vol. 129, N4. Pp. 359-366.

15. Juan H., Sametz W., Hiermann A. Anti-inflammatory effects of a substance extracted from Epilobium angustifolium // Agents and Actions. 1988. Vol. 23, N1-2. Pp.106-107.

16. Hiermann A., Mayr K. The investigation of active compounds from Epilobium species. The occurrence of sitosterol derivatives in Epilobium angustifolium L. and Epilobium parviflorum Schreb.// Scientia Pharmaceutica. 1985. Vol. 53, N1. Pp. 39-44.

17. Glen A.T., Lawrie W., McLean J., El-Garby Younes M. Triterpenoid constituents of rose-bay willow-gerb // J. Chem. Soc. C. 1967. Vol. 26, N6. Pp. 510-515. 
18. Ali M. S., Jahangir M., Shazad ul Hussan S., Choudhary M.I. Inhibition of $\alpha$-glucosidase by oleanolic acid and its synthetic derivatives // Phytochemistry. 2002. Vol. 60, N3. Pp. 295-299.

19. Sultana N., Ata A. Oleanolic acid and related derivatives as medicinally important compounds // Journal of Enzyme Inhibition and Medicinal Chemistry. 2008. Vol. 23, N6. Pp. 739-756.

20. Sun H., Fang W. S., Wang W. Z., Hu C. Structure-activity relationships of oleanane- and ursane type triterpenoids // Botanical Studies. 2006. Vol. 47, Pp. 339-368.

21. Jung S. H., Ha Y. J., Shim E. K., Choi S. Y., Jin J. L., Yun-Choi H. S., Lee J. R. Insulin-mimetic and insulin-sensitizing activities of a pentacyclic triterpenoid insulin receptor activator // Biochem. J. 2007. Vol. 403, N2. Pp. 243-250.

22. Liu J. Pharmacology of oleanolic acid and ursolic acid // Journal of Ethnopharmacology. 1995. Vol. 49, N2-1. Pp. 57-68.

23. Liu J., Sun H., Duan W. Maslinic Acid Reduces Blood Glucose in KK-Ay Mice// Biol. Pharm. Bull. 2007. Vol. 30, N11. Pp. 2075-2078.

24. Schmandke H. Ursolic acid and its derivatives with antitumor activity in berries of Vaccinium species // ErnährungsUmschau. 2004. Vol. 51, N6. Pp. 235-237.

25. Somova L. O., Nadar A., Rammanan, P., Shode F.O. Cardiovascular, antihyperlipidemic and antioxidant effects of oleanolic and ursolic acids in experimental hypertension // Phytomedicine. 2003. Vol. 10, N2-3. Pp. 115-121.

26. Ovesna Z., Kozics K., Slamenova D. Protective effects of ursolic acid and oleanolic acid in leukemic cells // Mutat. Res. 2006. Vol. 600, N1-2, Pp. 131-137.

27. Wachter G. A., Valcic S., Flagg M. L., Franzblau S. G., Montenegro G. E., Suarez E., Tommermann B. N. Antituber activity of pentacyclic triterpenoids from plants of Argentina and Chile // Phytomedicine. 1999. Vol. 6, N5. Pp. 341-345.

28. Vasconcelos F. C., Gattass C. R., Rumjanek V. M., Maia R. C. Pomolic acid-induced apoptosis in cells from patients with chronic myeloid leukaemia exhibiting different drug resistance profile // Investigational New Drugs. 2007. Vol. 25, N6. Pp. 525-533.

29. Miura T., Ueda N., Yamada K., et al. Antidiabetic Effects of Corosolic Acid in KK-Ay Diabetic Mice // Biol. Pharm. Bull. 2006. Vol. 29, N3. Pp. 585-587.

30. Yin M.C., Chan K.C. Nonenzymatic Antioxidative and Antiglycative Effects of Oleanolic Acid and Ursolic Acid // J. Agric. Food Chem. 2007. Vol. 55, N17. Pp. 7177-7181.

31. Ha Y. L., Grimm N.K, Pariza M.W. Newly recognized anticarcinogenic fatty acids: Identification and quantification in natural and processed cheeses // J. Agr. Food Chem. 1989. Vol. 37, N2. Pp. 75-81.

32. Ito H., Kasama K., Nasure S., Shimura K. Antitumor effect of palmitoleic acid on Ehrlich ascites tumor // Cancer letter. 1982. Vol. 17, N2. Pp. 197-203.

33. Visonneau S., Cesano A., Tepper S.A. et al. Conjugated linoleic acid suppresses the growth of human breast adenocarcinoma cells in SCID mice // Anticancer Res. 1997. Vol. 17, N2A. Pp. 969-973.

34. Yang B., Kallio, H. Composition and physiological effects of sea buckthorn (Hippophaë) lipids // Trends Food Sci. Technol. 2002. Vol. 13. Pp. 160-167.

35. Zeb A. Important therapeutic uses of sea buckthorn (Hippophae): a review // J. Biol. Sci. 2004. Vol. 4, N5. Pp. 687-693.

36. Zeb A. Anticarcinogenic potential of lipids from Hippophae - evidence from the recent literature // Asian Pac. J. Cancer Prev. 2006. Vol. 7, N1. Pp. 32-35. 


\section{Kukina T.P., Frolova T.S., Salnikova O.I. LIPOPHILIC ACIDS OF FIREWEED}

N.N. Vorozhtzov Novosibirskii Institute of Organic Chemistry of the Siberian Branch of Russian Academy of Sciences, Lavrent'eva ave., 9, Novosibirsk, 630090 (Russia), e-mail: kukina@nioch.ncs.ru

Mass-spectrometry chromatographic analysis of fireweed (Chamaenerion angustifolium (L.) Scorp.) lipophilic acid constituents has been carried out. 36 aliphatic and 5 triterpenic acids were found out at first time.

Keywords: fireweed, Chamaenerion angustifolium (L.), mass-spectrometry chromatographic analysis, lipophilic acid constituents.

\section{References}

1. Koroleva A.S., Krasnoborov I.M., Pen'kovskaia E.F. Opredelitel' rastenii Novosibirskoi oblasti. []. Novosibirsk, 1973, 368 p. (in Russ.).

2. Krasnoborov I.M., Lomonosova M.N., Shaulo D.N. Opredelitel' rastenii Novosibirskoi oblasti. [To plants of Novosibirsk Region]. Novosibirsk, 2000, 492 p. (in Russ.).

3. Takhtadzhian A.L. Zhizn' rastenii. T. 5, ch. 2. Tsvetkovye rasteniia. [Plant life. Volume 5, Part 2. Flowering plants.]. Moscow, 1980, 512 p. (in Russ.).

4. Hiermann A., Radl B. J. Chromatog. A., 1998, vol. 803, no. 1, pp. 311-314.

5. Ducrey, B., Wolfender, J.L., Marston, A., Hostettmann, K. Phytochemistry, 1995, vol. 38, no. 1, pp. 129-137.

6. Slacanin I., Marston A., Hostettmann K., Delabays N., Darbellay C. J. Chromatogr., 1991, vol. 557, no. 1-2, pp. 391-398.

7. Hiermann A. Scientia Pharmaceutica, 1995, vol. 63, no. 2, pp. 135-144.

8. Shmonov A.M. Novoe v biologii, khimii i farmakologii oblepikhi. [New in biology, chemistry and pharmacology of sea buckthorn.]. Novosibirsk, 1991, pp. 191-189. (in Russ.).

9. Polezhaeva I.V., Polezhaeva N.I., Meniailo L.N. Khimiia rastitel'nogo syr'ia, 2005, no. 4, pp. 67-70. (in Russ.).

10. Polezhaeva I.V., Polezhaeva N.I., Levdanskii V.A. Vestnik KrasGU, seriia «Estestvennye nauki», 2005, no. 2, pp. 130-133. (in Russ.).

11. Sapegin L.M., Daineko N.M., Timofeev S.F. Rastitel'nye resursy, 2008, vol. 44, no. 4, pp. 85-91. (in Russ.).

12. Polezhaeva I.V. Novye dostizheniia v khimii i khimicheskoi tekhnologii rastitel'nogo syr'ia: materialy IV vserossiiskoi konferentsii. [New advances in chemistry and chemical engineering plant materials: Proceedings of IV All-Russian Conference]. Barnaul, 2007, pp. 66-70. (in Russ.).

13. Hiermann A., Bucar F. J. Ethnopharmacol., 1997, vol. 55, pp. 179-183.

14. Velasco L., Goffman F.D. Botan. J. Linnean Soc., 1999, vol. 129, no. 4, pp. 359-366.

15. Juan H., Sametz W., Hiermann A. Agents and Actions, 1988, vol. 23, no. 1-2, pp.106-107.

16. Hiermann A., Mayr K. Scientia Pharmaceutica, 1985, vol. 53, no. 1, pp. 39-44.

17. Glen A.T., Lawrie W., McLean J., El-Garby Younes M. J. Chem. Soc. C., 1967, vol. 26, no. 6, pp. 510-515.

18. Ali M. S., Jahangir M., Shazad ul Hussan S., Choudhary M.I. Phytochemistry, 2002, vol. 60, no. 3, pp. $295-299$.

19. Sultana N., Ata A. Journal of Enzyme Inhibition and Medicinal Chemistry, 2008, vol. 23, no. 6, pp. 739-756.

20. Sun H., Fang W. S., Wang W. Z., Hu C. Botanical Studies, 2006, vol. 47, pp. 339-368.

21. Jung S. H., Ha Y. J., Shim E. K., Choi S. Y., Jin J. L., Yun-Choi H. S., Lee J. R. Biochem. J., 2007, vol. 403, no. 2 , pp. 243-250.

22. Liu J. Journal of Ethnopharmacology, 1995, vol. 49, no. 2-1, pp. 57-68.

23. Liu J., Sun H., Duan W. Biol. Pharm. Bull., 2007, vol. 30, no. 11, pp. 2075-2078.

24. Schmandke H. Ernährungs-Umschau, 2004, vol. 51, no. 6, pp. 235-237.

25. Somova L. O., Nadar A., Rammanan, P., Shode F.O. Phytomedicine, 2003, vol. 10, no. 2-3, pp. 115-121.

26. Ovesna Z., Kozics K., Slamenova D. Mutat. Res., 2006, vol. 600, no. 1-2, pp. 131-137.

27. Wachter G.A., Valcic S., Flagg M.L., Franzblau S.G., Montenegro G.E., Suarez E., Tommermann B.N. Phytomedicine, 1999, vol. 6, no. 5, pp. 341-345.

28. Vasconcelos F.C., Gattass C.R., Rumjanek V.M., Maia R.C. Investigational New Drugs, 2007, vol. 25, no. 6, pp. $525-533$.

29. Miura T., Ueda N., Yamada K., et al. Biol. Pharm. Bull., 2006, vol. 29, no. 3, pp. 585-587.

30. Yin M.C., Chan K.C. J. Agric. Food Chem., 2007, vol. 55, no. 17, pp. 7177-7181.

31. Ha Y. L., Grimm N.K, Pariza M.W. J. Agr. Food Chem., 1989, vol. 37, no. 2, pp. 75-81.

32. Ito H., Kasama K., Nasure S., Shimura K. Cancer letter, 1982, vol. 17, no. 2, pp. 197-203.

33. Visonneau S., Cesano A., Tepper S.A. et al. Anticancer Res., 1997, vol. 17, no. 2A, pp. 969-973.

34. Yang B., Kallio, H. Trends Food Sci. Technol., 2002, vol. 13, pp. 160-167.

35. Zeb A. J. Biol. Sci., 2004, vol. 4, no. 5, pp. 687-693.

36. Zeb A. Asian Pac. J. Cancer Prev., 2006, vol. 7, no. 1, pp. 32-35. 